\title{
ANALISIS PERBANDINGAN KINERJA LAYANAN INFRASTRUCTURE AS A SERVICE CLOUD COMPUTING PADA PROXMOX DAN XENSERVER
}

\author{
Surahmat $^{1}$, Alfred Tenggono ${ }^{2}$ \\ ${ }^{1,2}$ STMIK PalComTech \\ Email : '1surahmat@palcomtech.ac.id, 2alfred.tenggono@gmail.com
}

\begin{abstract}
ABSTRAK
Cloud computing ialah teknologi yang memanfaatkan internet sebagai layanan sehingga tidak terlalu banyak menggunakan komputer fisik karena sistem cloud computing menggunakan sistem virtual dimana dengan memperguanakan sebuah komputer saja bisa memberikan layanan kebanyak komputer sekaligus dengan sistem virtualisasi. Penelitian yang dilakukan oleh peneliti berfokus pada perbandingan kinerja layanan Infrastructure as a Service Cloud Computing dengan tujuan untuk mengetahui kelebihan dan kekurangan dari kedua jenis software dengan teknologi hypervisor tipe 1 yaitu Proxmox dan Xenserver. Metode yang digunakan dalam penelitian ini ialah menggunakan action research atau penelitian terapan. Skema pengujian yang dilakukan pada penelitian ini adalah pengujian CPU load dan memory usage, pengujian benchmark, pengujian network traffic, dan Pengambilan respons pengguna layanan. Hasil dari pengujian terhadap Xenserver dan Proxmox mendapatkan hasil respons yang baik untuk pengujian CPU load dan memory usage, pengujian benchmark, pengujian network traffic kemudian untuk hasil respons dari pengguna layanan Proxmox mendapat total nilai sebesar 3848 dan Xenserver sebesar 3739.
\end{abstract}

Kata kunci: IaaS, Proxmox, Xenserver, QoS

\begin{abstract}
Cloud computing is a technology that utilizes the internet as a service so that it does not use too many physical computers because the cloud computing system uses a virtual system where by using a computer alone it can provide services to many computers at the same time with a virtualization system. Research conducted by researchers focuses on comparing the performance of Infrastructure as a Service Cloud Computing services with the aim to finding out the strengths and weaknesses of the two types of software with type 1 hypervisor technology, namely Proxmox and Xenserver. The method used in this study is to use action research. The testing scheme conducted in this study is testing CPU load and memory usage, benchmark testing, network traffic testing, and retrieval of service user responsses. The results of testing on Xenserver and Proxmox get good responsse results for CPU load and memory usage testing, benchmark testing, network traffic testing then for responsse results from users Proxmox get a total value of 3848 and Xenserver 3739.
\end{abstract}

Keywords: IaaS, Proxmox, Xenserver, QoS

Author Korespondensi (Surahmat)

Email : surahmat@palcomtech.ac.id

\section{PENDAHULUAN}

Perkembangan teknologi komputer terutama dibidang internet semakin mempermudah dalam melakukan kegiatan sehari-hari mulai dari pekerjaan hingga pertukaran informasi, sehingga membuat semakin tingginya kebutuhan akan resource dari komputer mulai dari perangkat CPU, media menyimpanan, hingga kebutuhan memori.
Hal ini juga yang menyebabkan biaya perawatan dan operasional semakin meningkat. Untuk meringankan biaya operasioan dan perawatan dari komputer dapat menggunakan teknologi cloud computing, teknologi ini ialah teknologi yang memanfaatkan internet sebagai layanan sehingga tidak terlalu banyak menggunakan komputer fisik karena sistem cloud computing menggunakan sistem virtual 
dimana dengan memperguanakan sebuah komputer saja bisa memberikan layanan untuk banyak komputer sekaligus dengan sistem virtualisasi [1].

Teknologi cloud computing ini juga akan meringankan biaya oprasional dan perawatan dari komputer karena hanya menggunakan sedikit komputer fisik. Disamping itu juga teknologi cloud computing dapat digunakan secara fleksibel artinya dapat diakses dimanapun dengan terkoneksi ke dalam jaringan internet secara on-line, kemudian apabila kita tidak ingin menggunakan komputer fisik bisa juga melakukan penyewaan layanan cloud computing sehingga lebih menghemat dalam penggunaan biaya opersional dan perawatan komputer [2]. Adapun layanan cloud computing yang dapat digunakan sebagai Layanan Infrastructure as a Service anatara lain adalah Proxmox dan Xenserve. Kedua software tersebut dapat memberikan layanan cloud computing dengan jenis Infrastructure as a Service dengan teknologi hypervisor tipe 1 atau Baremetal Architecture dimana nanti software ini akan langsung bertindak sebagai sistem operasi pada perangkat komputer fisik [3]. Masalah yang timbul dalam penggunan layanan cloud computing ialah pengguna kurang atau bahkan tidak mengetahui keunggulan dan kelemahan dari jenis-jeni layanan dari cloud computing tersebut sehingga dibutuhkan sebuah analisis yang memberikan perbandingan dari kenerja layanan cloud computing tersebut sehingga pengguna akan mengetahu kelemahan dan kekurangan dari cloud computing yang akan mereka gunakan serta dapat memberikan masukan mengenai teknologi seperti apa yang dibutuhkan oleh pengguna.

Penelitian terdahulu mengenai analisis kinerja suatu layanan cloud computing dapat kita lihat dari penelitian yang dilakukan oleh Wikranta Arsa dan Khabib Mustofa pada penelitian ini menggunakan virtualisasi server Proxmox VE dan didapatkan pencapaian kinerja turnaround time, responsse time, serta troughput. Serta dengan menggunakan sistem cloud Proxmox VE dapat memaksimalkan kinerja dari CPU hingga 100\% [4]. Sedangkan penelitian yang dilakukan oleh peneliti berfokus pada perbandingan kinerja layanan Infrastructure as a Service Cloud Computing dengan tujuan untuk mengetahui kelebihan dan kekurangan dari kedua jenis software dengan teknologi hypervisor tipe 1 yaitu Proxmox dan Xenserver. Dikarenakan kedua software ini adalah software yang banyak digunakan Infrastructure as a Service pada Cloud Computing.

\section{METODOLOGI}

Metode yang digunakan dalam penelitian ini ialah menggunakan action research atau penelitian tindakan merupakan salah satu bentuk rancangan penelitian, dalam penelitian tindakan peneliti mendeskripsikan, menginterpretasi dan menjelaskan suatu situasi sosial pada waktu yang bersamaan dengan melakukan perubahan atau intervensi dengan tujuan perbaikan atau partisipasi [5]. Adapun tahapan dari action research adalah sebagai berikut

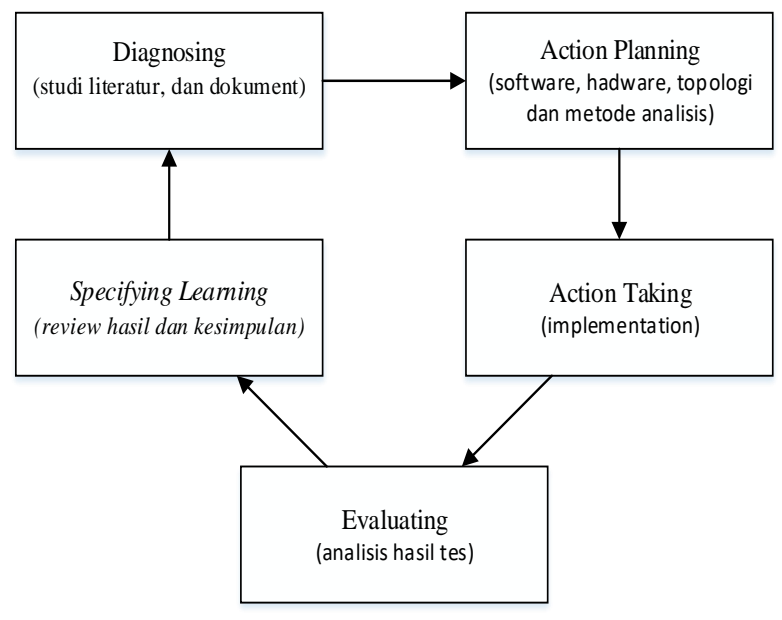

Gambar 1. Metode Penelitian

\section{Diagnosing}

Pada tahapan ini dilakukan identifikasi masalahmasalah pokok pada penelitian, dilakukan dengan cara melakukan studi literatur mengenai Infrastructure as a Service cloud computing dengan menggunakan Proxmox dan Xenserver, dengan mempelajari penelitian terdahulu serta dokumen lain yang berkaitan dengan penelitian yang penulis lakukan.

\section{Action Planning}

Pada tahapan ini dilakukan pemahaman tentang pokok masalah yang ada kemudian dilanjutkan dengan menyusun rencana tindakan yang tepat untuk menyelesaikan masalah tersebut. Rencana tindakan yang dilakukan antara lain adalah 
meyiapakan kebutuhan hardware dan software, melakukan instalasi software, analisis jaringan untuk pengujian, serta metode pengujian yang dilakukan pada Proxmox dan Xenserver untuk mengetahui kualitas layanan.

\section{Action Taking}

Pada tahapan ini dilakukan implementasi rencana tindakan dengan melakukan implementasi langsung berdasarkan rencana yang telah dibuat sebelumnya, implementasi ini dilakukan pada lab jaringan STMIK Palcomtech. Pada tahapan ini juga dilakukan pengambilan respons dari pengguna mengenai kinerja dari Proxmox dan Xenserver menggunakan kuesioner.

\section{Evaluating}

Setelah masa implementasi (action taking) dianggap cukup kemudian peneliti melaksanakan evaluasi hasil dari implementasi. Guna untuk mengetahui data apa yang telah didapat berdasarkan prosedur kerja yang telah dibuat.

\section{Learning}

Pada tahapan ini dilakukan review hasil yang didapat dari tiap tahapan dengan melakukan kembali perbandingan data hasil implementasi dengan studi literature berdasarkan penelitian dan dokumen mengenai cloud computing. Kemudian dibuat kesimpulan mengenai hasil dari penelitian yang telah dilakukan.

\section{HASIL DAN PEMBAHASAN}

Berikut hasil yang didapat dari penelitin yang dilakukan .

\section{Diagnosing}

Pada tahapan ini dilakukan review antara lain mengengenai fitur dari masing-masing software cloud computing yang akan di ujicoba yaitu Proxmox dan Xenserver [6].

Tabel 1. Perbandingan Fitur

\begin{tabular}{lcc}
\hline \multicolumn{1}{c}{ Fitur } & Proxmox & Xenserver \\
\hline Live Migration & $\sqrt{ }$ & $\sqrt{ }$ \\
Hight Availability & $\sqrt{ }$ & $\sqrt{ }$ \\
Storage Migration & $\sqrt{ }$ & $\sqrt{ }$ \\
VM Cloning & $\sqrt{ }$ & $\sqrt{ }$
\end{tabular}

GUI \& CLI Features

VM Snapshots

Capacity Planning

Virtual Firewall

VM Backup/Restore

Thin Provisioning

Config Mapping

Performance Reports

Failover

Dev \& Testing

Kemudian juga dilakukan studi literatur tentang penelitian terdahulu yang telah dilakukan misalnya penelitian yang dilakukan oleh Wikranta Arsa dan Khabib Mustofa [4], penelitian oleh Arif Arfiandi [7], dan penelitian yang dilakukan oleh Muhammad Fauzan, Andrew Fiade, dan Fenty Eka M. A. [8]. Selain penelitian terdahulu juga di review dokumen lain yang berkaitan tentang penelitian yang dilakukan misalanya dokumen panduan instalasi, buyer guide virtual server software, dan product documentation.

\section{Action Planning}

Pada tahapan ini dilakukan rencana tindakan antara lain adalah rencana kebutuhan hardware dan software, rencana instalasi software, rancangan jaringan untuk pengujian, serta menyaiapkan langkah pengujian berdasarkan metode yang digunakan.

Tabel 2. Kebutuhan Hardware dan software

\begin{tabular}{ll}
\hline \multicolumn{1}{c}{ Hardware } & \multicolumn{1}{c}{ Software } \\
\hline Procesor Intel ${ }^{\circledR}$ Core & Citrix Xenserver 7.6 \\
I5-4440 & \\
Ram 2x 4Gb (8GB) & Proxmox VE 5.2-1 \\
Storage Segate 500Gb & Ubuntu 16.04LTS \\
- & Windows 7 \\
\hline
\end{tabular}

Pengujian yang dilakukan menggunakan beberapa software untuk melihat kinerja layanan dari Proxmox dan Xenserver software tersebut antara lain adalah iperf 3, unixbench 5.1.3, wireshark 2.6.8, dan siege 4.0.4. Sedangkan topologi jaringan yang digunakan pada pengujian adalah sebagai berikut. 


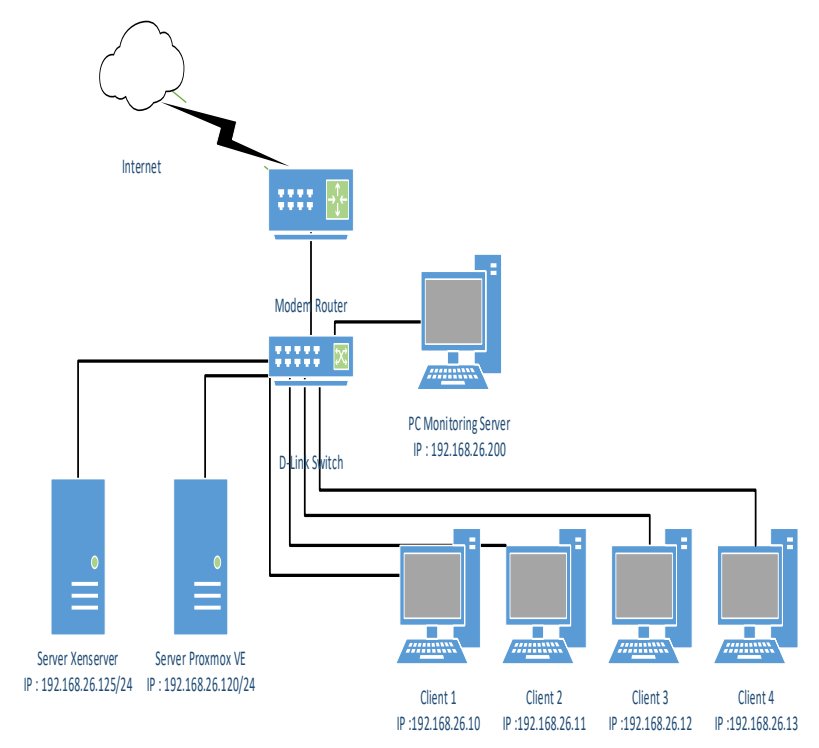

Gambar 2. Topologi Jaringan

Pada saat pengujian menggunakan dua buah server yaitu server yang terinstall Proxmox dengan IP address 192.168.26.120/24 dan Xenserver dengan IP address 192.168.26.125/24. Kemudian digunakan sebuah PC sebagai pusat melakukan monitoring sekaligus management server dengan IP address 192.168.26.200/24. Untuk client dalam topologi pengujian yang digunakan menggunakan IP address 192.168.26.10/24 - 192.168.26.113/24 semua perangkat tersebut terhubung dalam jaringan menggunakan kabel UTP CAT 5e menggunakan sebuah Hub D-Link.

Langkah pengujian yang dilakukan dibuat dalam bentuk flowchat agar setiap tahapan dapat didokumentasikan dengan baik.

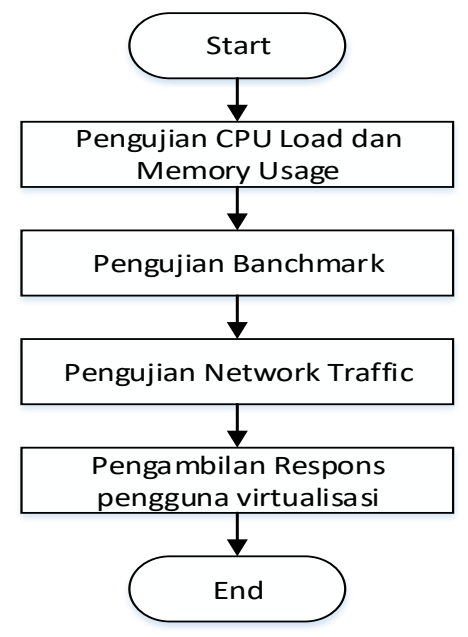

Gambar 3. Langkah Pengujian

\section{Action Taking}

Pada tahapan ini dilakukan pengujian dengan software pengujian atau tools yang telah disiapkan dengan skema pengujian sebagai berikut.

1. Pengujian $C P U$ load dan Memory Usage

2. Pengujian Benchmark

3. Pengujian Network Traffic

4. Pengambilan respons pengguna layanan

Pada setiap tahapan action taking setiap hasil yang didapat akan di dokumentasikan dan kemudian akan dipergunakan pada tahapan selanjutnya.

\section{Pengujian $C P U$ load dan Memory Usage}

Pengujian dari CPU load dan Memory Usage pada Xenserver mengunakan XenCenter yaitu software yang digunakan untuk memonitoring dan manajement Xenserver. Kemudian pengujian Proxmox dilakukan dengan web browser dengan memanggil alamat dari server Proxmox yang digunakan.

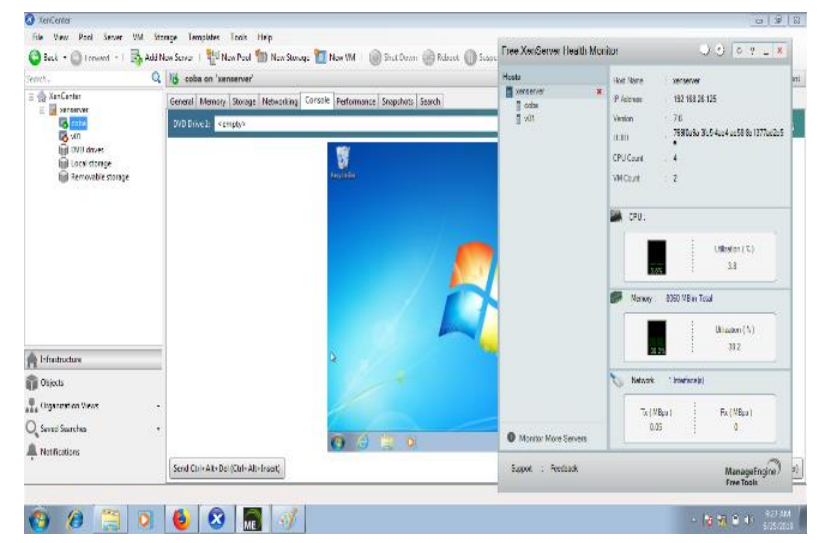

Gambar 3. Pegujian Kondisi Idle

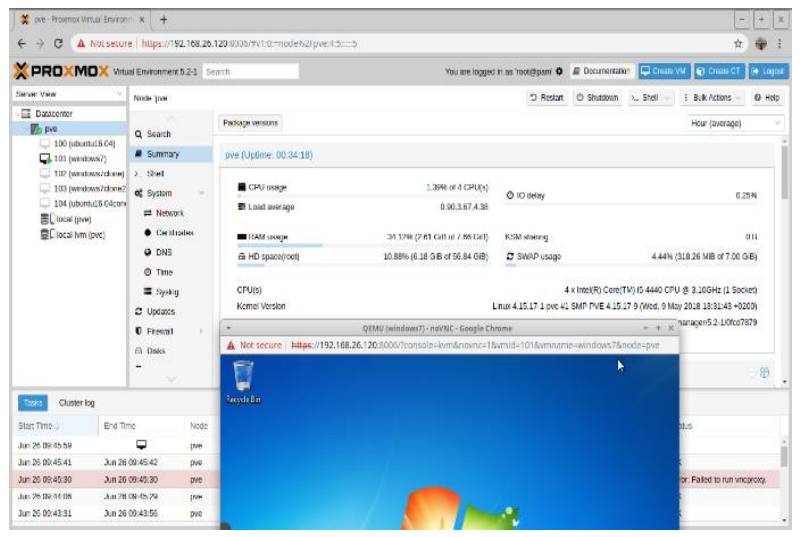

Gambar 4. Pengujian Kondisi Running Browser 
Pengujian dilakukan dengan dua kondisi yaitu kondisi idle dan saat kondisi running dengan melakukan browsing internet pada mesin virtualisasi yang dijalankan.

\section{Pengujian Benchmark}

Pengujian benchmark dilakukan untuk melihat kempuan dari XenServer dan Proxmox saat menangani beban kerja dengan mengirimkan paket data yang banyak untuk diperoses didalam Xenserver maupun Proxmox tools pengujian yang digunakan adalah unixbanch 5.1.3.

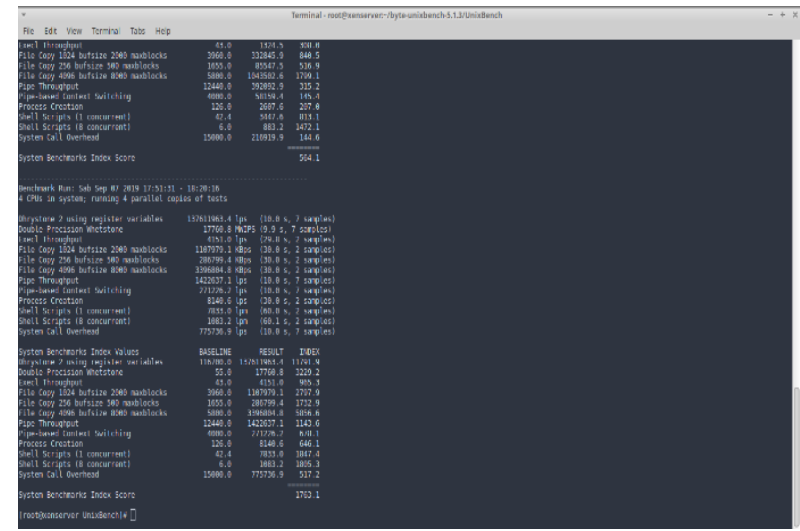

Gambar 5. Pengujian Benchmark Xenserver

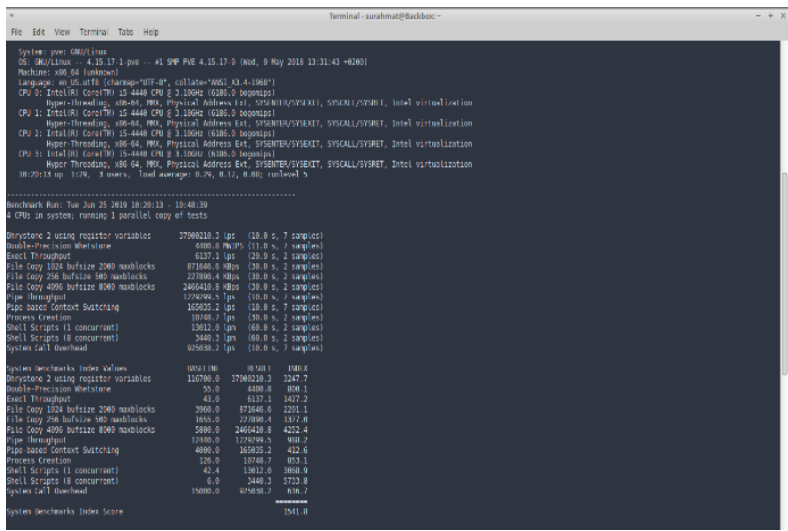

Gambar 6. Pengujian Benchmark Proxmox

\section{Pengujian Network Traffic}

Pengujian Network Traffic dilakukan untuk melihat kemampuan jaringan saat sedang menggunakan Xenserver dan Proxmox dikarenakan semua kegiatan yang dilakukan pada kedua server virtualisasi tersebut maupun pada sistem operasi virtual yang terinstal dijalankan melalui jaringan, sehingga perlu diketahui kemampuan dari jaringan saat menangani beban kerja yang sedang berlangsung akibat dari kegiatan yang dilakukan di dalam jaringan yang digunakan. Pengujian network traffic pada penelitian ini menggunakan iperf3 dan wireshark

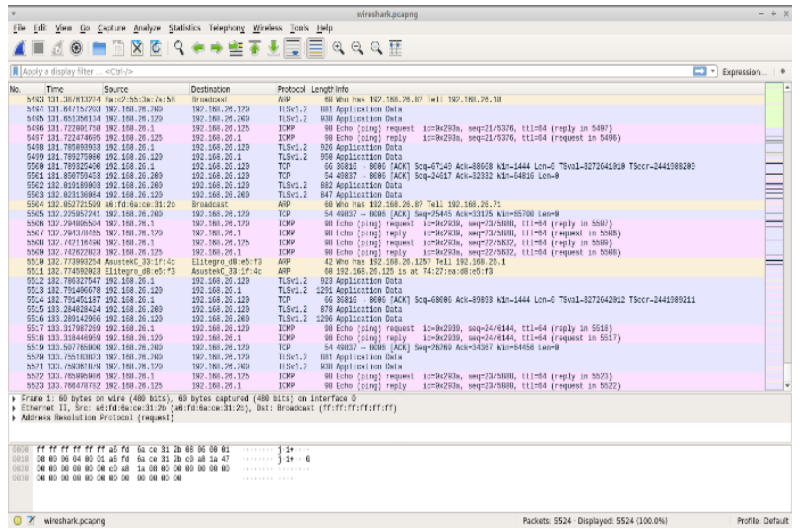

Gambar 7. Pengujian menggunakan Wireshark

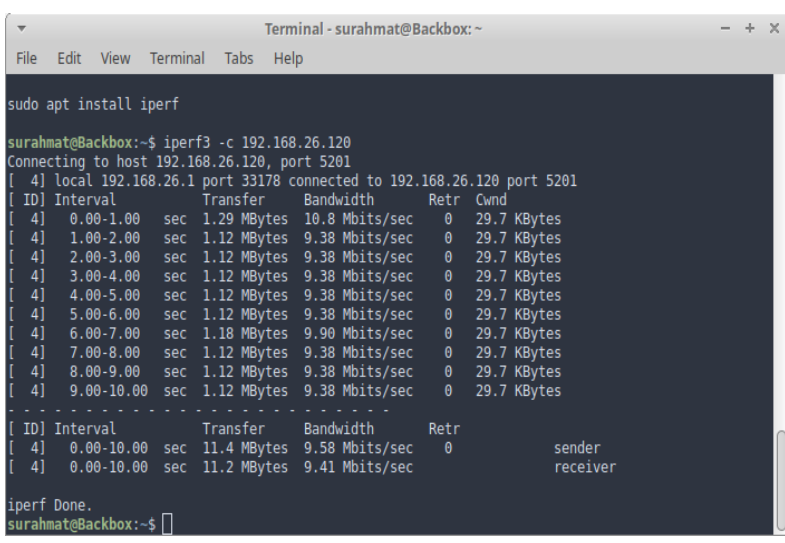

Gambar 8. Pengujian menggunakan Iperf

4. Pengambilan respons pengguna layanan

Respons pengguna layanan didapatkan dengan membagikan sebanyak 50 kuesioner kepada responden, responden yang diambil responsnya ialah orang yang pernah menggunakan Xenserver dan Proxmox adapun point pertanyaan kuesioner mengaju pada panduan indikator dari Technology Acceptance Model berupa persepsi akan kemanfaatan, sikap penggunaan, persepsi akan kemudahan penggunaan, perilaku untuk tetap menggunakan, dan kondisi nyata dalam penggunaan sistem [9].

Tabel 3. Pertanyaan Kuesioner

\begin{tabular}{cccc}
\hline \multicolumn{2}{c}{ Xenserver } & \multicolumn{2}{c}{ Proxmox } \\
\hline Indikator & Kode & Indikator & Kode \\
\hline Pertanyaan 1 & XEU1 & Pertanyaan 20 & PEU1 \\
Pertanyaan 2 & XEU2 & Pertanyaan 21 & PEU2 \\
Pertanyaan 3 & XEU3 & Pertanyaan 22 & PEU3
\end{tabular}




\begin{tabular}{llll} 
Pertanyaan 4 & XEU4 & Pertanyaan 23 & PEU4 \\
Pertanyaan 5 & XUS1 & Pertanyaan 24 & PUS1 \\
Pertanyaan 6 & XUS2 & Pertanyaan 25 & PUS2 \\
Pertanyaan 7 & XUS3 & Pertanyaan 26 & PUS3 \\
Pertanyaan 8 & XUS4 & Pertanyaan 27 & PUS4 \\
Pertanyaan 9 & XAT1 & Pertanyaan 28 & PAT1 \\
Pertanyaan 10 & XAT2 & Pertanyaan 29 & PAT2 \\
Pertanyaan 11 & XAT3 & Pertanyaan 30 & PAT3 \\
Pertanyaan 12 & XAT4 & Pertanyaan 31 & PAT4 \\
Pertanyaan 13 & XIU1 & Pertanyaan 32 & PIU1 \\
Pertanyaan 14 & XIU2 & Pertanyaan 33 & PIU2 \\
Pertanyaan 15 & XIU3 & Pertanyaan 34 & PIU3 \\
Pertanyaan 16 & XIU4 & Pertanyaan 35 & PIU4 \\
Pertanyaan 17 & XAU1 & Pertanyaan 36 & PAU1 \\
Pertanyaan 18 & XAU2 & Pertanyaan 37 & PAU2 \\
Pertanyaan 19 & XAU3 & Pertanyaan 38 & PAU3 \\
\hline
\end{tabular}

\section{Evaluating}

Pada tahapan ini dianalisis semua data yang telah dikumpulkan pada saat tahapan action taking melalui tahapan pengujian dan pengaambilan respons dari pengguna. Data yang telah dianalisis kemudian akan digunakan sebagai simpulan pada tahapan selanjutnya.

\section{Hasil Pengujian CPU load dan Memory Usage}

Hasil dari pengujian yang dilakukan untuk CPU load dan Memory Usage pada penelitian ini menggunakan dua jenis pengujian yaitu pada kondisi running dan idel, dengan masingmasing menguji 1 virtual sistem operasi, 2 virtual sistem operasi dan 4 virtual sistem operasi.

Tabel 4. Hasil Pengujian

CPU load dan Memory Usage

\begin{tabular}{lcccc}
\hline \multirow{2}{*}{ Pengujian } & \multicolumn{2}{c}{ Xenserver } & \multicolumn{2}{c}{ Proxmox } \\
\cline { 2 - 5 } & $\begin{array}{c}\text { CPU } \\
\text { Load }\end{array}$ & $\begin{array}{c}\text { Memori } \\
\text { Usage }\end{array}$ & $\begin{array}{c}\text { CPU } \\
\text { Load }\end{array}$ & $\begin{array}{c}\text { Memori } \\
\text { Usage }\end{array}$ \\
\hline Runing & & & & \\
\hline 1 VOS & $19 \%$ & $39.2 \%$ & $25 \%$ & $18,9 \%$ \\
2 VOS & $25 \%$ & $49,3 \%$ & $32 \%$ & $23,6 \%$ \\
4 VOS & $34 \%$ & $83,5 \%$ & $40 \%$ & $75,5 \%$ \\
\hline Idel & & & & \\
\hline 1 VOS & $6 \%$ & $39,2 \%$ & $4,6 \%$ & $11,2 \%$ \\
2 VOS & $8 \%$ & $49,3 \%$ & $9,5 \%$ & $20,3 \%$ \\
4 VOS & $13 \%$ & $83,5 \%$ & $20 \%$ & $74,2 \%$ \\
\hline
\end{tabular}

Pengujian dilakukan dengan menggunakan sistem operasi Ubuntu 16.04LTS yang diberikan memori $1 \mathrm{~Gb}$ dan sistem operasi windows 7 yang diberikan memori $2 \mathrm{~Gb}$.

\section{Hasil Pengujian Benchmark}

Hasil dari pengujian yang dilakukan pada tahapan ini menggunakan sistem benchmark index score dengan indikator yang anatara lain adalah file copy, shell scripts, dan system call overhead.

Tabel 5. Hasil Pengujian Benchmark

\begin{tabular}{lcc}
\hline \multirow{2}{*}{ Pengujian } & \multicolumn{2}{c}{ Hasil } \\
\cline { 2 - 3 } & Xenserver & Proxmox \\
\hline 1 parallel copy of test & 564,1 & 1541,8 \\
4 parallel copy of test & 1763.1 & 3820,8 \\
Time for Clone Ubuntu & 15,33 & 6,42 \\
16.04LTS & 16,20 & 6,8 \\
Time for Clone & & \\
Windows 7 & \\
\hline
\end{tabular}

Pada pengujian menggunakan fitur clone Xenserver memiliki fitur fast clone yang memungkinkan clone dilakukan dengan waktu sekitar 15 detik, sedangkan Proxmox tidak memiliki fitur fast clone sehingga apabila membuat clone hanya ada satu pilihan menu.

\section{Hasil Pengujian Network Traffic}

Hasil pengujian pada tahapan ini didapat dengan melakukan uji Quality of service (QoS) dengan beberapa indikator seperti bandwith, troughput, delay, dan paket loss [10].

Tabel 6. Hasil Pengujian Network Traffic

\begin{tabular}{lll}
\hline \multirow{2}{*}{\multicolumn{1}{c}{ Pengujian }} & \multicolumn{2}{c}{ Hasil } \\
\cline { 2 - 3 } & \multicolumn{1}{c}{ Xenserver } & \multicolumn{1}{c}{ Proxmox } \\
\hline Bandwith Sender & $9,55 \mathrm{Mb} / \mathrm{s}$ & $9,58 \mathrm{Mb} / \mathrm{s}$ \\
Bandwith Reciver & $9,44 \mathrm{Mb} / \mathrm{s}$ & $9,41 \mathrm{Mb} / \mathrm{s}$ \\
Troughput & $2,38 \mathrm{MB} / \mathrm{s}$ & $2.45 \mathrm{MB} / \mathrm{s}$ \\
Delay & $0,428 \mathrm{~ms}$ & $0,459 \mathrm{~ms}$ \\
Paket Loss & $0,06 \%$ & $0,04 \%$ \\
\hline
\end{tabular}

4. Hasil Pengambilan respons pengguna layanan

Respons pengguna layanan didapatkan dengan membagikan sebanyak 50 kuesioner kepada responden dengan jumlah pertanyaan sebanyak 38. Pertanyaan tersebut dibuat berdaarkan indikator yang diambil dari Technology Acceptance Model adapun hasil dari pengambilan kuesioner adalah sebagai berikut. 
Tabel 7. Hasil Kuesioner

\begin{tabular}{cccc}
\hline \multicolumn{2}{c}{ Hasil Kuesioner } & \multicolumn{2}{c}{$\begin{array}{c}\text { Hasil Kuesioner } \\
\text { Proxmox }\end{array}$} \\
\hline Konserver & Total & Kode & Rata-rata \\
Pertanyaan & Jawaban & Pertanyaan & Jawaban \\
\hline XEU1 & 206 & PEU1 & 210 \\
XEU2 & 211 & PEU2 & 212 \\
XEU3 & 203 & PEU3 & 208 \\
XEU4 & 203 & PEU4 & 207 \\
XUS1 & 190 & PUS1 & 195 \\
XUS2 & 195 & PUS2 & 202 \\
XUS3 & 200 & PUS3 & 195 \\
XUS4 & 204 & PUS4 & 200 \\
XAT1 & 196 & PAT1 & 205 \\
XAT2 & 206 & PAT2 & 206 \\
XAT3 & 203 & PAT3 & 207 \\
XAT4 & 209 & PAT4 & 209 \\
XIU1 & 205 & PIU1 & 211 \\
XIU2 & 201 & PIU2 & 201 \\
XIU3 & 94 & PIU3 & 144 \\
XIU4 & 202 & PIU4 & 208 \\
XAU1 & 205 & PAU1 & 212 \\
XAU2 & 203 & PAU2 & 208 \\
XAU3 & 203 & PAU3 & 208 \\
\hline
\end{tabular}

Setelah dapatkan hasil dari kuesioner yang disebarkan maka data tersebut di analisis sehingga didapatkan perolehan hasil dari tiap idikator yang digunakan, sebagai panduan penilaian hasil kuesioner menggunakan table rentang nilai penilaian berdasarkan rumus rentang nilai responden

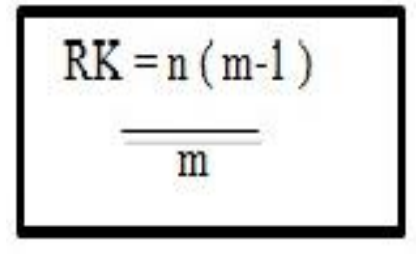

Gambar 9. rumus rentang nilai responden

Sehingga didapat rentang nilai penilaian sebagai berikut.

Tabel 8. Rentang nilai responsden

\begin{tabular}{cl}
\hline Rentang nilai & \multicolumn{1}{c}{ Keterangan } \\
\hline $50-90$ & Sangat Buruk/Sangat Rendah \\
$91-130$ & Buruk/Rendah \\
$131-170$ & Cukup/Sedang \\
$171-210$ & Baik/Tinggi \\
$211-250$ & Sangat Baik/Sangat Tinggi \\
\hline
\end{tabular}

Setelah diketahu hasil dari table rentang nilai responden, kemudian data hasil kusioner dianalisis sehingga diketahui hasil dari tiap-tiap indikator yang digunakan yaitu sebagai berikut.

Tabel 9. Hasil Analisis Kuesioner

\begin{tabular}{lcccc}
\hline \multirow{2}{*}{ Indikator } & \multicolumn{2}{c}{ Xenserver } & \multicolumn{2}{c}{ Proxmox } \\
\cline { 2 - 5 } & Nilai & Hasil & Nilai & Hasil \\
\hline $\begin{array}{l}\text { Persepsi } \\
\text { kemudahan }\end{array}$ & 205.75 & Baik & 209.25 & Baik \\
$\begin{array}{l}\text { Persepsi } \\
\text { kemanfaatan }\end{array}$ & 197.25 & Baik & 198 & Baik \\
$\begin{array}{l}\text { Sikap } \\
\text { Penggunaan }\end{array}$ & 203.5 & Baik & 206.75 & Baik \\
$\begin{array}{l}\text { Perilaku tetap } \\
\text { menggunakan }\end{array}$ & 175.5 & Baik & 191 & Baik \\
$\begin{array}{l}\text { Kondisi nyata } \\
\text { penggunaan }\end{array}$ & 203.66 & Baik & 209.33 & Baik \\
\hline
\end{tabular}

\section{SIMPULAN DAN SARAN \\ 1. Simpulan}

Simpulan dari penelitian yang telah dilakukan dibuat dengan menggunakan Specifying Learning dimana seluruh hasil yang penulis dapatkan dilakukan review kembali sehingga didapatkan kesimpulan berupa :

a. Xenserver dan Proxmox mampu menjalankan sistem vitualisasi dengan baik ini terlihat dari penggunaan CPU dan memori dimana dari hasil pengujian didapat kan penggunaan CPU pada Proxmox lebih besar disbanding dengan Xenserver, tetapi penggunaan memori lebih besar pada Xenserver dibanding dengan Proxmox seperti saat menjalankan 4 virtual sistem operasi pada Xeserver menggunakan CPU $34 \%$ dan memori $83,5 \%$ sedangkan pada proxmox penggunaan CPU $40 \%$ dan memori $74,2 \%$

b. Pada pengujian Benchmark Proxmox lebih unggul dibanding dengan Xenserver dengan nilai pengujian pada parallel copy of test pada Proxmox sebesar 3820.8 untuk pengujian 4 parallel copy of test dan Xeserver sebesar 1763.1. tetapi Xenserver memiliki fitur unggulan berupa fast clone sehingga waktu clone dari sebuah virtual sistem operasi hanya membutuhkan waktu sekitar 15 detik.

c. Untuk pengujian network traffic baik Xenserver maupun Proxmox memiliki nilai 
pengujian yang hampir sama dengan penilaian QoS sangat baik dengan nilai untuk Xenserver pada troughput 2,38 $\mathrm{MB} / \mathrm{sec}$, delay $0,428 \mathrm{~ms}$, dan paket loss $0,06 \%$. Kemudian untuk Proxmox pada troughput $2,45 \mathrm{MB} / \mathrm{sec}$, delay $0,459 \mathrm{~ms}$, dan paket loss $0,04 \%$.

d. Untuk hasil dari respons pengguna Xenserver dan Proxmox mendapatkan hasil respons yang baik untuk semua indikator yang diujikan walaupun Proxmox sedikit lebih unggul dengan total nilai perlolehan dari responden dengan nilai total 3848 dan Xenserver sebesar 3739.

\section{Saran}

Penelitian yang telah penulis lakukan masih memiliki beberapa kekurangan sehingga penulis memberikan saran berupa :

a. Dilakukan perbandingan mengenai security dari Xenserver dan Proxmox sehingga diketahui tingkat security dari masingmasing server virtualisasi.

b. Untuk penggunaan Xenserver maupun Proxmox sebaiknya ditambahkan sebuah mesin sebagai backup dari sistem tersebut dikarenakan penggunaan server vitualisasi yang terpusat apabila terjadi masalah pada server vitualisasi yang digunakan dapat dipulihkan dengan mesin backup.

\section{UCAPAN TERIMA KASIH}

Pada kesempatan ini penulis mengucapkan terima kasih kepada semua pihak yang telah membatu dalam menyelesaikan penelitian ini. Ucapan terima kasih disampaikan pada.

1. KEMENRISTEKDIKTI sebagai penyandang dana penelitian.

2. Ketua STMIK Palcomtech yang telah memberikan izin tempat pelaksanaan penelitian.

3. Kepala LPPM STMIK Palcomtech yang telah membantu terkait penelitian dan publikasi.

\section{REFERENSI}

[1] D. J. Prince, "Introduction to cloud computing," J. Electron. Resour. Med. Libr., 2011.

[2] P. G. S. C. Nugraha, I. Komang Ari Mogi, and I. Made Agus Setiawan, "Implementasi
Private Cloud Computing Sebagai Layanan Infrastructure As A Service (IAAS) Menggunakan Openstack," Ilm. Ilmu Komput., 2015.

[3] D. Pousa and J. Rufino, "Evaluation of Type-1 Hypervisors on Desktop-Class Virtualization Hosts," IADIS Int. J. Comput. Sci. Inf. Syst., 2017.

[4] Arsa W and Mustofa K, "Perancangan dan Analisis Kinerja Private Cloud Computing dengan Layanan Infrastructure-As-AService (IAAS) ," J. IJCCS, vol. 8, no. 2, pp. 165-176, 2014

[5] S. Kemmis, R. McTaggart, and R. Nixon, "The action research planner," Action Res. Plan. Doing Crit. Particip. Action Res., 2014.

[6] "Comparative Analysis Of Proxmox VE And Xenserver As Type 1 Open Source Based Hypervisors," Int. J. Sci. Technol. Res., vol. 7, no. 3, pp. 72-77, 2018.

[7] Arief Arfriandi, "Perancangan, implementasi, dan Analisis Kinerja Virtualisasi Menggunakan Proxmox Esx, Vmware dan Openstack," J. Teknol., 2012.

[8] M. Fauzan, A. Fiade, and F. E. M. A, "Infrastruktur Private Cloud Dengan Openstack," J. Pseudocode, pp. 180-189, 2017.

[9] N. Marangunić and A. Granić, "Technology acceptance model: a literature review from 1986 to 2013," Univers. Access Inf. Soc., 2015.

[10] D. Ardagna, G. Casale, M. Ciavotta, J. F. Pérez, and W. Wang, "Quality-of-service in cloud computing: modeling techniques and their applications," J. Internet Serv. Appl., 2014. 